\title{
GERAKAN DAKWAH JAMA'AH TABLIGH DI KALANGAN WANITA DALAM PEMBINAAN KELUARGA MUSLIM DI KOTA BANDARLAMPUNG
}

\author{
Muhamad Bisri Mustofa \\ Institut Agama Islam Agus Salim Metro \\ Jl. Brigjend. Sutiyoso No. 7, Kota Metro, 34111, Lampung \\ muhamadbisrimustofa@gmail.com
}

\begin{abstract}
Since the emergence of the Transnational Da'wah Movement such as the Tablighi Jama'at, it has created contradictions about the Law of Providing both birth and mentality to the family left in the Khuruj fii sabilillah program (Exiting the Way of Allah) to preach the ummah from house to house, mosque to mosque, inviting listen to Muslims (religious lectures) and invite to pray in congregation in the mosque. From the development of Jama'ah Tabligh's missionary movement in Indonesia, this movement has experienced quite rapid development. Not only is the movement that has a strong community, it is marked by the presence of da'wah markers (da'wah centers) in each of the Provinces and Districts of the City. But in the development of the da'wah movement there are several things that become contradictions in the family, in this case the provision of income for children and wives who are left behind when their head of household implements Khuruj fii sabilillah for 3 days, 40 days and 4 months. Therefore, this paper takes the theme of the Law of Livelihood Against Families in the Tabligh Jama Da'wah Movement in a comprehensive manner.
\end{abstract}

Key Words: Family Livelihood, Da'wah Movement, Jama'ah Tabligh.

\begin{abstract}
Abstrak
Sejak Munculnya Gerakan Dakwah Transnasional seperti Jama"ah Tabligh menimbulkan kontradiksi tentang Hukum Memberikan Nafkah baik lahir maupun batin terhadap keluarga yang di tinggalkan dalam program Khuruj fii sabilillah (Keluar di Jalan Allah) untuk berdakwah mendatangi ummat dari rumah ke rumah, masjid ke masjid, mengajak mendengarkan ta"lim (ceramah agama) dan mengajak melaksanakan sholat berjamaa"h di masjid. Dari perkembangan gerakan dakwah Jama"ah Tabligh ini di Indonesia, gerakan ini telah mengalami perkembangan yang cukup pesat. Tidak saja menjadi gerakan yang memiliki Jama"ah cukup pesat ditandai dengan adanya markaz dakwah (pusat dakwah) disetiap Provinsi dan Kabupaten Kota. Namun dalam perkembangan gerakan dakwah tersebut terdapat beberapa hal yang menjadi kontradiksi dalam keluarga, dalam hal ini adalah pemberian nafkah kepada anak dan istri yang di tinggalkan ketika kepala rumah tangga mereka melaksanakan Khuruj fii sabilillah selama 3 hari, 40 hari dan 4 bulan. Oleh sebab itu, tulisan ini mengambil tema Hukum Nafkah Terhadap Keluarga pada Gerakan Dakwah Jama"ah Tabligh secara komprehensif.
\end{abstract}

Kata Kunci : Gerakan Dakwah, Jama"ah Tabligh.

\section{Pendahuluan}

Dalam perjalanan manusia kepada kebahagian hidup di dunia dengan berkeluarga, memiliki pendamping hidup dan keturunan. Pernikahan merupakan salah satu bentuk ibadah dan bagian dari pada ibadah terpanjang seorang Hamba. Pernikahan juga merupakan peristiwa hukum yang sangat penting dalam 
kehidupan manusia dengan berbagai konep hukumnya. Karena itu hukum mengatur masalah pernikahan ini secara detail. Yang dimaksud dengan perkawinan adalah suatu ikatan lahir dan batin antara seorang pria dan wanita sebagai suami istri dengan tujuan untuk membentuk suatu kelurga (rumah tangga) yang bahagia dan kekal berdasarkan ketuhanan yang maha esa, yang harus juga dicatat menurut peraturan perundang-undangan yang berlaku. Lihat pasal 1 dan pasal 2 undang-undang Perkawinan No. 1 Tahun 1974.1

\section{Pengertian Gerakan Dakwah}

Gerakan dakwah atau lebih sering dikenal dengan dakwah harakah bermakna dakwah dengan atau melalui sistem pergerakan. Sesuai dengan namanya, aliran dakwah yang satu ini lebih menekankan aspek tindakan (aksi) ketimbang wacana (teoritisasi). ${ }^{2}$ Menurut Hasan al-Qattany, yang dimaksud dakwah harakah adalah dakwah yang berorientasi pada pengembangan masyarakat Islam, dengan melakukan reformasi total (islah) terhadap seluruh aspek kehidupan social, baik terkait dengan individu (islah alfard), keluarga (islah al-usrah), masyarakat (islah al-mujtama')hingga Negara (islah aldaulah). ${ }^{3}$

Kata Harakah itu sendiri secara harfiah berarti gerak atau gerakan, merupakan lawan dari diam (al-Harakah Dlidl al-Sukun). Dikatakan bergerak, bila seorang berpindah atau mengambil posisi baru. ${ }^{4}$ Dan makna harfiah ini, dapat dipahami dua makna penting kata harakah. Pertama, harakah, menunjuk pada suatu gerakan yang timbul setelah masa atau kondisi vakum. Kedua, harakah menunjuk pada suatu usaha pembaruan untuk membawa masyarakat kepada kehidupan baru yang lebih baik. ${ }^{5}$

1 Munir Fuady, Konsep Hukum Perdata, PT Raja Grafindo Persada, (Jakarta: 2014), h. 10. Islam, (Jakarta : Prenada Media Group, 2011), Cet. Ke-1, h. 233

${ }^{3}$ Hasan Ibn Falah al-Qattany, al-Tariq ila al-Nahdah al-Islamiyyah, (Riyad : Dar al-Hamidi, 1993), h. $1-10$

${ }^{4}$ Raghib al-Ashfahani, al-Mufradat fi Gharib al-Qur'an, (Beirut Libanon : Dar al-Ma'rifah, tt.), h. 114. Lihat pula, Ibn Manzhur, Lisan al-Arab, (Beirut : Dar Shadir, 1990), Cet. Ke-1, h. 410-411

Ibid, h. 410-411 
Harakah (movement), menurut Kalim Siddiqui, merupakan watak Islam. Dikatakan bahwa Islam (lahir) menjadi suatu gerakan dan akan selalu menjadi grakan. Gerakan Islam bertujuan mendirikan dan melindungi Negara Islam demi kesejahteraan dan kebahagiaan hidup di dunia maupun di akhirat. "The Islamic Movement is the struggle of The Muslims to establish, maintain, develop,devend, extend,or re-establish the Islamic state as an instrument to enjoin good and firbid evil for the walfare, and happiness for the mankind in this world and in the hereafter. ,,that the while Islamic state coud be lost, the Islamic movement itself was on-going and could no be lost.",

Dalam perkembangannya dakwah harakah dilihat dari segi substansi dan cakupannya, dakwah harakah mengklaim memiliki ruang gerak yang lebih komprehensif dari pada dakwah pengembangan masyarakat. Jika dalam perkembangannya dakwah harakah dalam melihat keterlibatan dan independensi dari unsur politik dan membatasi gerakanya lebih pada ruang lingkup pendidikan dan pembangunan ekonomi, namun dakwah harakah lebih menilai politik sebagai salah satu bagian yang tak terpisahkan dari sistem Islam, karena dakwah tidak bisa dilepaskan dari politik. Dalam pandangan paradigma harakah, Islam itu disimbolkan dengan 3D, din (agama), daulah (negara), dan dunya (dunia). ${ }^{8}$

Kemunculan paradigma dakwah bukan hanya berlatar belakang doktrin tersebut ansich, tetapi juga ada factor historis, yakni keterpurukan umat Islam pasca kolonialisme di satu sisi, dan kebangkitan Islam disisi yang lain. ${ }^{9}$

6 A. Ilyaz Ismail, Paradigma Dakwah Sayyid Quthub : Rekonstruksi Pemikiran Dakwah Harakah, (Jakarta : Permadani, 2006), Cet.Ke-1, h. 12-13

${ }^{7}$ Simi Niazi, A New Paradigm in the Making, dalam Kalim Siddiqui (Ed.) Issues in the Islamic Movement 1980-1981 (1400-1401), (London-Toronto-Pretoria : The Open Press Limited, 1982), h. 330-331

8 Ilyas Ismail dan Prio Hotman, Filsafat Dakwah..., Op.Cit., h. 233

9 Yusuf al-Qardawy, Sahwat al-islamiyah wa Humun al-Watan al-'Arab wa al-Islami, (Kairo : Makhtabah Wahbah, 1997), h. 29 
Menurut Ibrahim al-Ja'bari, dakwah harakah sebagai paradigma yang memadukan dimensi pemikiran (konsepsional) dan pergerakan (praktikal), mulai eksis bermunculan di negeri-negeri Islam sejak permulaan abad ke-20 silam dan karenanya model-model dakwah ini banyak diadopsi, misalnya, pergerakan Islam kontemporer Ikhwanul Muslimin di Mesir, Nur Khuluq di Turki, Revolusi Islam di Iran, dan Jama'ati Islam di anak benua India-Pakistan. 10

Dari segi kebahasaan, kata harakah dapat diartikan sebagai gerak atau gerakan; arti ini dapat kata ini dapat dikontraskan dengan kata al-sukun yang berarti diam (din alsukun). Dari pemahaman kebahasaan ini, sesuatu yang bergerak itu ditandai jika terdapat perpindahan dari suatu tempat atau itu kondisi ke tempat atau konsidi lainnya. Jika dikaitkan dengan dakwah, maka dakwah yang menghendaki pergerakan dari konsidi vakum sebelumnya, atau menghendaki suatu usaha pembaharuaan untuk membawa masyarakat kepada kehidupan baru yang lebih baik. ${ }^{11}$

Bagi pendukung mazhab ini harakah bukanlah sekedar pandangan atau penafsiran, lebih dari itu, harakah adalah watak dasar bagi suatu gerakan dan akan selalu menjadi gerakan. $^{12}$ Islam tidak dibatasi hanya sebagai agamanya (din), tetapi juga harus diyakini sebagai aturan hidup bermasyarakat (dunya) dan aturan menjalankan pemerintahan (daulah). Paradigma dakwah harakah menegaskan perlunya meyakini Islam sebagai sistem hidup yang komprehensif (manhaj hayah). ${ }^{13}$

2. Tinjauan Gerakan Dakwah Dari Berbagai Aspek

${ }^{10}$ Ibrahim Muhammad al-Ja'bari, Gerakan Kebangkitan Islam, alih bahasa Abu Ayyub al-Ansary, (Solo : Duta Rohman, 1996), h. 67-70

${ }^{11}$ Abu Mufdal al-Raghib al-Ashifany, al-Mufradat fi Gharib Al-Qur'an, (Damaskus : Dar Qalam, tt.), Juz 1, h. 226

${ }^{12}$ A. Ilyaz Ismail, Paradigma Dakwah Sayyid Quthub Rekonstruksi Pemikiran Dakwah Harakah, (Jakarta :Penamadani, 2006), h. 12

${ }^{13}$ Muhammad al-Ghazali, Fi Maukib al-Da'wah, (Kairo : Maktabah Nahdah al-Misr, 2005), h. 163 
Sebagai sistem hidup yang komprehensif (manhaj hayah) menurut Fathi Yakan, Islam tidak boleh dianggap hanya sebagai sistem keyakinan transedental, melainkan suatu sistem yang mengatur seluruh segi kehidupan dari mulai sistem social, ekonomi hingga politik. ${ }^{14}$ Khusus aspek politik, Fathi Yakan membedah karakter harakah Islam dari sistem keyakinan lain. Islam kata Yakan, berbeda dengan agama Kristen misalnya, yang menghendaki pemisahan agama dari Negara. Dalam keyakinan Kristen, agama tidak mencampuri urusan-urusan keagamaan. Kaidah yang amat terkenal terkait dengan pemisahan agama dari Negara ini adalah pernyataan “...berikanlah kaisar milik kaisar dan berikanlah kepada Allah apa yang menjadi milik Allah... "15. Fatih Yakan memaparkan, bahwa kaidah demikian ini tidak dikenal dalam Islam. Kekuasaan Negara, demikian Fatih Yakan menjelaskan, sejatinya ditujukan untuk melindungi agama dan menghadirkan keadilan dalam masyarakat. ${ }^{16}$

Yusuf Qardawy menambahkan, Negara dalam sistem perpolitikan bukanlah sesuatu yang lain dari agama. Agama, begitu Yusuf Qardawy, adalah sebuah sistem ilmiah lengkap (al-Nizâm al-Ilâhi as-Syamîl) yang mencakup pola aturan tentang penyelenggaraan pemerintahan. Konsep pemisahan antara agama dari Negara, lanjut Yusuf Qardawy, selanjutnya bukan lahir dari pemahaman Islam yang benar, tetapi dari pemahaman sekuler yang di impor dari Barat. ${ }^{17}$

Melalui cara pandang ini, aliran dakwah harakah bermaksud untuk menjadikan Islam (hukum Islam) sebagai satu-satunya undang-undang dalam kehidupan, bukan saja kehidupan pribadi (al-ahwal al-syakhsyîyyah), tetapi kehidupan bermasyarakat (al-

\footnotetext{
${ }_{15}^{14}$ Fathi Yakan, Kaifa Nad'u ila al-Islam, (Beirut : Muassasah al-Risalah, 1991), h. 89

15 Ibid., h. 97

${ }^{16}$ Ibid., h. 88

${ }^{17}$ Yusuf Qardawy, Min Fiqh ad-Daulah fi al-Islam, (Kairo : Dar as-Syuruq, 2001), h. 14
} 
ahwal al-ijtîma'iyyah), dan kehidupan bernegara (al-ahwal ad-dauliyyâh). ${ }^{18}$ Untuk tujuan itu secara teoritis paradigma dakwah harakah membuat dikotomi antara sistem Islam dan sistem jahiliyyah. Sistem Islam adalah suatu sistem masyarakat yang dibangun diatas undang-undang ilahiah, yakni syariat Islam. Masyarakat yang dibangun dengan sistem ini disebut masyarakat Islam (al-mujtamâ' al-Islamŷ) dan merupakan cita-cita atau tujuan dari diturunkannya Al-Qur'an. Lawannya adalah sistem jahiliah, yakni sistem hidup bermasyarakat yang dibangun atas undang-undang buatan manusia (hukum sekuler) atau (al-qanan al-wad'iyyâhlah al-ardiyyâh), dan masyarakat yang hidup di dalamnya disebut masyarakat jahiliyyah (al-mujtamâ'al-jahily). ${ }^{19}$

Kejahilan menurut pendukung mazhab ini, bukanlah suatu kehidupan manusia, tetapi sebagai kondisi yang dapat hinggap dalam masyarakat mana pun dan kapan pun. Dahulu, dakwah Nabi Muhammad Saw digerakan sebagai upaya untuk mendekontruksi sistem jahiliah Arab dan membangun sistem Islam. Melalui undang-undang Al-Qur'an, dakwah Nabi Muhammad Saw berhasil mentransformasikan masyarakat Arab jahiliah dan membentuk sebuah masyarakat Islam seperti disaksikan sejarah. Bahkan menurut Sayyid Quthub, satu-satunya generasi al-qur'an (Jilun Quranîyyun Farid) yang hingga kini belum ada padananannya, dan sepertinya memang tidak pernah ada, berhasil diwujudkan melalui gerakan dakwah Muhammad Saw. ${ }^{20}$

Dakwah harakah saat ini perlu dihadirkan demi merekontruksi masyarakat jahiliyah masa sekarang (Jahiliyyat al-Isryin) dan mengulangi kesuksesan dakwah seperti masa Nabi. $^{21}$ Dari sudut pandang metode dakwah, pendekatan yang diterapkan mengikuti cara berfikir mazhab dakwah harakah yang sebetulnya dalam beberapa hal ada

\footnotetext{
Sahwah, 1993), h. 89

${ }_{19}$ Sayyid Quthub, Nahwa Mujtama’ Islamy, (Kairo : Dar al-Syuruq, 1993), h. 64

${ }^{20}$ Sayyid Quthub, Maalim fi al-Tariq, (Kairo : Dar al-Syuruq, 1979), h. 13

${ }^{21}$ Sayyid Quthub, Tafsir Fi Zilal Al-Qur'an, (Mauqi al-Tafsir), Juz 4, h. 25
}

${ }^{18}$ Yusuf Qardawy, Syari'at al-Islam as-Salihat li al-Tatbiq fi kulli zaman wa Makan, (Kairo : Dar al- 
kesamaanya dengan mazhab pengembangan masyarakat. Kesamaan itu misalnya dapat ditelaah dari usulan dakwah harakah tentang sosialisasi tauhid sebagai asas pembangunan masyarakat, kebangkitan intelektual dan ekonomi atau kritik keduanya terhadap mazhab dakwah tabligh. Namun, demikian, mazhab dakwah harakah berangkat lebih jauh ketika mengusulkan dakwah yang harus mencakup perbaikan Negara atau pemerintahan. Untuk tujuan itu, dakwah harakah mengambil jalur pendekatan dakwah massif. Pendekatan dakwah itu misalnya terlihat dari konsep dakwah jihad atau perang suci untuk mewujudkan pemerintahan Islam. ${ }^{22}$

Menurut mazhab ini, pemerintahan Islam bukanlah alternative (pilihan), melainkan imperative (kewajiban). Untuk itu, umat Islam diwajibkan untuk mewujudkan cita-cita tersebut, jika tidak dapat dilakukan dengan perubahan dari dalam secara structural, maka pendekatan dakwah meningkat dalam wujud yang massif, perang suci. Umat muslim, menurut mazhab ini, wajib melawan dan menghancurkan setiap kekuatan yang menghalang-halangi dakwah untuk mewujudkan pemerintahan Islam. Bahkan Sayyid Quthub, salah seorang penggagas mazhab dakwah ini menegaskan, semua musuh Islam, baik dari kelompok Barat maupun golongan elite muslim yang menghalangi terbentuknya pemerintahan Islam dan penerapan syariat Islam, adalah kaum elite yang mesti ditumpas dalam perang suci oleh mereka yang beriman. ${ }^{23}$

Ketegasan ini dimaskudkan untuk membebaskan manusia dari penyembahan sesama manusia atau yang disebut tagût (tirani). Dalam pemerintahan yang menerapkan syariat Islam, manusia akan berdiri sederajat dengan menusia lainnya di hadapan Allah Swt. Kesetaraan atau egalitarianism itu tidak mungkin dapat terwujud kecuali jika Negara menerapkan undang-undang berdasarkan syariat Allah saja. Manusia, menurut

\footnotetext{
${ }_{23}^{22}$ A. Ilyaz Ismail, Paradigma Dakwah Sayyid..., Op.cit., h. 176

${ }^{23}$ Ibid., h. 76
} 
cara pandang ini, tidak memiliki wewenang apapun untuk menguasai manusia lainnya. Lebih dari itu, mereka hanya diberi amanat untuk mengurus rakyat dan menciptakan keadilan bernegara dengan perantaraan undang-undang syariat. Sebaliknya, manusia dilarang untuk tunduk pada ketentuan apa pun kecuali ketentuan yang dating dari Allah.

Untuk itu pemimpin Negara tidak berhak membuat ketentuan berdasarkan ketentuan jahiliah, yang bukan berasal dari syariat. Sebaliknya mereka dituntut untuk mengatur rakyatnya berdasarkan undang-undang syariat dan mereka juga memiliki kewajiban untuk tunduk dibawah undang-undang ini. Penyalahan akan prinsip tersebut, akan termasuk dalam sistem jahiliah, dan umat muslim sama-sama memiliki tanggung jawab untuk mengubah sistem ini, dengan jalan damai jika masih bias, atau dengan perang suci jika kendali memang menghendaki demikian. ${ }^{24}$

Untuk mencapai cita-cita, maka pendekatan dakwah mesti dilakukan pertama-tama adalah pembentukan gerakan. Pembentukan gerakan ini dimaksudkan untuk menciptakan pendukung utama atau jama'ah inti. Gerakan ini dibentuk dalam sebuah ikatan solidaritas keimanaan dan memiliki tanggung jawab untuk pengembangan Islam dan lingkungannya, memperluas wilayah dan jaringannya sehingga dakwah Islam dapat menyebar keseluruh penjuru dunia. 25

Gerakan-gerakan dakwah ini mesti dibina dan dididik dengan tauhid yang mantap, karena mereka itu sejatinya mereka akan dibentuk menjadi agen-agen tauhid diseluruh dunia. Mereka juga dibina (tarbiyyah) dalam satu pelatihan (liqâ') supaya memiliki kualitas ibadah dan akhlak yang baik agar terampil dalam melakukan pengaturan atau pengoraganisasian (tanzim) terhadap pergerakan dakwah. ${ }^{26}$ Kemudian pendekatan harakah dilanjutkan dengan membentuk suatu distingtif (mufassalah) antara pergerakan

\footnotetext{
${ }^{24}$ Ibid., h. 158

25 Ibid., h. 257

${ }^{26}$ Ibid., h. 259
} 
dakwah yang berlandaskan Islam dan pergerakan lain yang berlandaskan sistem jahiliah. Pembedaan ini terbilang sangat urgen demi mencegah terjadinya pencampuradukan antara kedua sistem yang tidak dapat dikompromikan itu. Dalam konteks kehidupan bermasyarakat pemisahan itu dimaksudkan untuk mencegah terjadinya peleburan pemahaman yang merupakan akses kepada distorsi-distorsi atas ajaran dakwah yang benar. 27

Mazhab dakwah harakah patut mendapat apresiasi terutama ide-idenya yang berhasil mengangkat derajat dan martabat dakwah Islam dari anggapan bahwa dakwah sekedar tabligh. Mazhab dakwah harakah juga layak mendapat apresiasi terutama karena idenya yang mampu untuk menghadirkan pandangan dakwah yang lebih holistis dan komperhensif. Hadirnya mazhab harakah mampu menjadi inspirasi bagi banyak gerakan dakwah lainnya, yang menyandarkan bahwa dakwah sejatinya mesti lebih banyak aspek praktikal melebihi terorientasi. Karena bagaimanapun juga kehadiran dakwah ditujukan untuk melakukan perubahan, sedangkan perubahan ini memerlukan lebih banyak tindakan (lisan al-Hal) melampaui ucapan (lisan al-maqal).

Dari sudut pandang teologis, sebetulnya paradigma harakah ini memiliki kedekatan dengan dakwah salafi atau yang dikenal dengan wahaby. Dalam pemetaan pemikiran pembaruan, dakwah harakah yang dikarsai oleh ulama-ulama negeri pyramid seperti alBana, Sayyid Quthub, Fathi Yakan dan kemudian diteruskan oleh Yusuf Qordhowy ini, memiliki corak pemikiran yang cenderung konserfatif-revivalis. Disebut konsefatif karena berusaha untuk melestarikan paham orthodoksi Islam dan bersikap apriori (acuh) bahkan kerap mecurigai usaha-usaha pembaharuan (modernisasi). ${ }^{28}$ Disebut juga

\footnotetext{
${ }^{27}$ Ibid., h. 271

28 Modernisasi adalah usaha mendamaikan Islam dengan situasi alam modern. Penegasan ini diperlukan, sebab gerakan-gerakan Islam konservatif juga mengklaim mengadakan pembaruan Islam, namun dengan pengertian yang berbeda. Menurut yang terakhir ini, pembaruaan atau tajdid bukanlah modernisasi,
} 
revivalis, karena pemikiran yang menjadi ideologi gerakan dakwah ini berusaha menghidupkan tradisi atau nilai-nilai Islam lama di masa kini dan sangat bersemangat dalam mendakwahkan ide puritanisme. ${ }^{29}$

Sepeninggal syahidnya Sayyid Quthub, Yusuf Qardhawy kemudian menjadi tokoh yang fatwa-fatwanya banyak di adopsi dalam gerakan dakwah harakah. Secara pemikiran, Yusuf Qordhowy dinilai banyak orang cendrung lebih moderat dibanding para pendahulunya, dan dengan kemoderatannya itu ia berhasil mendapatkan banyak simpatisan termasuk gerakan dakwah al-ikhwan al-muslimin. Dengan kemodalannya itu pula, Yusuf Qordhowy mendapatkan kecaman dari gerakan dakwah ultra konservatif yang menganggapnya sebagai ahli fikir yang ingkar sunnah. Terlepas dari pro kontra itu, dari ukuran intelektual muslim seperti Hasan Hanafi dan Muhammad Arkoun, menurut Lutfhi Assakanie, Yusuf Qordhowy tetap dinilai sebagai ulama konservatif dan karena itu, dakwah harakah yang sekarang ini banyak mengdahapi ide-ide Yusuf Qordhowy menurut banyak penelitian tetap bercorak gerakan konservatif. ${ }^{30}$

Karakter dakwah harakah yang cenderung massif dan eksklusif (terutama karena konsep 'uzlah dan mufassalah), dinilai banyak kalangan sebagai berseberangan dengan nilai-nilai kebijakan lokal (Sophia perennis) dan cenderung idealis. Oleh karena itu, dalam perkembangannya, praktik dakwah harakah lebih sering mengalami benturanbenturan dengan budaya local dan kebijakan penguasa setempat. ${ }^{31}$ Pada akhirnya, dan demi kelangsungannya, secara factual, dakwah harakah mau tidak mau mengalami tarik ulur dengan konteks keindonesiaan misalnya, PKS dengan klaimnya sebagai partai

tetapi Islamisasi alam modern, yaitu gerakan menjadikan alam modern ini sesuai dengan syariat Islam. Menurut Luthfi Assyukanie, konsep yang terakhir ini bukan pembaruaan (reformation), tetapi lebih tepat disebut pengulangan (restatement). Lutfhi Assyukanie, Islam Benar Versus Islam Salah, (Jakarta : Kata Kita, 2007), h. 11 h. 205

${ }^{29}$ Jhon L, Esposito, Islam The Straight Path, alih bahasa Arif Mafthuhin, (Jakarta : Paramadina, 2004),

${ }^{30}$ Lutfhi Assakaine, Islam Benar Versus..., Op.cit., h. 179

${ }^{31}$ Ilyas Ismail dan Prio Hotman, Filsafat Dakwah..., Op.cit., h. 243 
dakwah (mazhab harakah), telah beberapa kali melakukan perubahan pendekatan. ${ }^{32}$ Segi kekurangan inilah yang nantinya menjadi kritikan dan disempurnakan oleh mazhab dakwah cultural, yaitu mazhab dakwah yang lebih indigenous dengan pendekatan kebudayaan dan peradabannya. 33

\section{Karakteristik Gerakan Dakwah}

Menurut Mustafa Masyhur, dakwah harakah mendasarkan diri pada tiga kekuatan sekaligus, yaitu (1) kekuatan aqidah dan iman, (2) kekuatan persatuan dan ikatan kaum muslimin (quwwat at-waddah wa at-tarabbuth) dan (3) kekuatan jihad (quwwat al jihad). ${ }^{34}$

Menurut Fathi Yakan, ada empat cirri yang sangat menonjol dari dakwah harakah, yaitu (1) murni dan autentik (dzatiyyah), yakni autentik sebagai panggilan Tuhan, (2) mendorong kemajuan (taqaddumiyah), yakni kemajuan yang tetap menjunjung tinggi nilai-nilai moralitas, (3) universal (syamilahi) mencakup semua aspek kehidupan, memadukan tiga sistem hidup (manhaj al hayat) yang terdiri dari tiga D, yaitu Din (agama), Dunya (dunia), dan Daulah (pemerintahan negara) dan (4) menekankan prinsip-prinsip agama yang luhur dan menjauhkan diri dari perbedaan mazhab. ${ }^{35}$

Menurut Sayyid Qutub, seorang aktifis dan arsitek dakah gerakan di Mesir ada tiga ciri dakwah gerakan, yaitu : (1) lebih menekankan pada aksi ketimbang teori, wacana dan retorika, sebagaimana dakwah Nabi yang tidak membangun wacana (la yuqim falsafatan) tetapi membangun ummat (lakin yubni ummah), (2) dakwah gerakan membolehkan penggunaan kekuatan fisik dalam membentuk jihad fisabilillah jika keadaan memaksakan. Jihad diperlukan untuk mengawal dakwah dan membela diri dari

\footnotetext{
${ }^{32}$ Ibid., h. 242

33 Ibid., h. 243

${ }^{34}$ Faizah \& Lalu Muchsin, Psikologi Dakwah, (Jakarta : Kencan, 2006), Edisi Pertama, Cet. Ke-2, h. xvi

${ }^{35}$ Ibid, h. xvi
} 
gerakan fisik yang menghalangi dakwah, dan (3) dakwah gerakan sangat meniscayakan organisasi dan jaringan (networking), dalam skala nasional, regional, maupun internasional. Menurut Sayyid Qutub, dakwah bukan saja tugas individual, tetapi tugas dan kewajiban kolektif seluruh muslim. Organisasi dakwah gerakan haruslah bersifat terbuka yang dibangun di atas platform akidah tauhid dan ukhuwah Islam tanpa mengenal perbedaan suku, ras, dan warna kulit. ${ }^{36}$

\section{Da'i Gerakan Dakwah}

Suatu pergerakan pasti memerlukan dukungan kader. Kader dakwah gerakan adalah da'i, tetapi da'i dalam paradigma gerakan, yaitu pejuang dakwah (mujahid ad-da'wah). Disini, da'i adalah seorang pejuang dan aktifis pergerakan Islam, yang sudah membekali diri dengan ilmu, wawasan dan ghirah dinnîyah sehingga tabah menghadapi ejekan, siksaan fisik dan bahkan siap menjadi syahid. Semboyan mujahid dakwah adalah Allâhû muqshadunâ (Allah tujuan kita), Al-Qur'an imâmunâ (Al-Qur'an imam kita), wa Sunnah sabîlinâ (sunnah nabi jalan kita), dan al-mautu fî sabîlillâh amanunâ (mati syahid harapan kita). ${ }^{37}$

\section{Kepentingan Gerakan Dakwah}

Perberlakian dakwah gerakan tidak sepanjang zaman, tetapi hanya jika keadaan memaksa, yaitu (1) ketika dakwah dihambat oleh kekuatan fisik, sehingga sama sekali tidak ada peluang untuk menyebarkan Islam (berdakwah) secara damai, (2) ketika ada kesiapan pada kaum muslimin, kesiapan mental, moral, dan kekuatan, (3) penggunaan kekuatan fisik dalam dakwah gerakan bersifat darurat. Jika keadaan kembali menjadi

\footnotetext{
${ }^{36}$ Ibid., h. xvii

37 Ibid., h. xvii
} 
kondusif untuk berdakwah secara damai, maka penggunaan kekuatan fisik harus dihentikan. $^{38}$

Perbedaan Islam di berbagai belahan bumi berbeda-beda dan untuk mengambil keputusan merespons keadaan diperlukan pemikiran mendalam serta ijtihad yang ikhthiyath (hati-hati) karena rentan terhadap penyusupan pihak lawan, seperti yang dialami oleh Jama'ah Islamiyah yang dipimpin oleh Abu Bakar Ba'asyir dan Habib Riziq, juga lasykar jihad Ja'far Umar, dan lasykar jihad Imran. 39

\section{Penggerakan Dakwah}

Adapun pengertian penggerakan dakwah adalah seluruh proses pemberian motivasi kerja kepada para bawahan sedemikian rupa, sehingga mereka mampu bekerja dengan ikhlas demi tercapainya tujuan organisasi dengan efisien dan ekonomis. Motiving secara implicit berarti, bahwa pimpinan organisasi di tengah bawahannya dapat memberikan sebuah bimbingan, intruksi, nasihat, dan koreksijika diperlukan. ${ }^{40}$ Agar fungsi dari penggerakan dakwah ini dapat berjalan secara optimal, maka harus menggunakan teknik-teknik tertentu meliputi: ${ }^{41}$

a. Memberikan penjelasan secara komprehensif kepada seluruh elemen dakwah yang ada dalam organisasi dakwah.

b. Usahakan agar setiap pelaku dakwah menyadari, memahami, dan menerima baik tujuan yang telah diterapkan.

c. Setiap pelaku dakwah mengerti struktur organisasi yang dibentuk

d. Memperlakukan secara baik bawahan dan memberikan penghargaan yang diiringi dengan bimbingan dan petunjuk untuk semua anggotanya.

\footnotetext{
${ }^{38}$ Ibid., h, xvii

${ }^{39}$ Ibid., h. xviii

${ }^{40}$ M. Munir \& Wahyu Ilaihi, Manajemen Dakwah, (Jakarta : Kencana, 2009), Cet. Ke-2, h. 139

41 Ibid, h. 139
} 
Dari semua potensi dan kemampuan ini, maka kegiatan-kegiatan dakwah akan teakomodir sampai kepada sasaran yang telah ditetapkan. Ada beberapa poin dalam proses pergerakan dakwah yang menjadi kunci dari kegiatan dakwah, yaitu :

a. Pemberian motivasi

b. Bimbingan

c. Penyelenggaraan komunikasi, dan

d. Pengembangan dan peningkatan pelaksana. ${ }^{42}$

\section{A. Strategi Gerakan Dakwah}

1. Pengertian Strategi Dakwah

Strategi dakwah adalah metode siasat, taktik atau manuver yang dipergunakan dalam aktivitas dakwah. ${ }^{43}$ Asmuni menambahkan, strategi dakwah yang dipergunakan dalam usaha dakwah harus memperhatikan beberapa hal, antara lain:

a. Azas filosofi, yaitu azas yang membicarakan tentang hal-hal yang erat hubungannya dengan tujuan yang hendak dicapai dalam proses dakwah;

b. Azas psikologi, yaitu azas yang membahas tentang masalah yang erat hubungannya dengan kejiwaan manusia. Seorang da'i adalah manusia, begitu juga sasaran atau objek dakwah yang memiliki karakter kejiwaan yang unik, sehingga ketika terdapat hal-hal yang masih asing pada diri mad'u tidak diasumsikan sebagai pemberontakan atau distorsi terhadap ajakan;

c. Azas sosiologi, yaitu azas yang membahas masalah-masalah yang berkaitan dengan situasi dan kondisi sasaran dakwah, misalnya politik masyarakat setempat, mayoritas agama di daerah setempat, filosofi sasaran dakwah, sosio-

\footnotetext{
${ }^{42}$ Abdul Rosyad Shaleh, Manajemen Dakwah Islam, (Jakarta : Bulan Bintang, 1993), Cet. Ke-3, h. 112

43 Asmuni Syukir, Dasar-Dasar Strategi Dakwah Islam (Surabaya: Al-Ikhlas, 1983), h. 32-33.
} 
kultur dan lain sebagainya, yang sepenuhnya diarahkan pada persaudaraan yang kokoh, sehingga tidak ada sekat diantara elemen dakwah, baik kepada objek ( $m a d ' u$ ) maupun kepada sesama subjek (pelaku dakwah).

Dalam mencoba memahami keberagamaan masyarakat, antara konsepsi psikologi, sosiologi dan religiusitas hendaknya tidak dipisahkan secara ketat, sebab jika terjadi akan menghasilkan kesimpulan yang fatal. ${ }^{44}$

d. Azas kemampuan dan keahlian (achievement and profesional), yaitu azas yang lebih menekankan pada kemampuan dan profesionalisme subjek dakwah dalam menjalankan misinya. Latar belakang subjek dakwah akan dijadikan ukuran kepercayaan mad'u;

e. Azas efektifitas dan efisiensi, yaitu azas yang menekankan usaha melaksanakan kegiatan dengan semaksimal mungkin sesuai dengan planning yang telah ditetapkan sebelumnya. $^{45}$

Seluruh azas yang dijelaskan di atas termuat dalam metode dakwah yang harus dipahami oleh pelaku dakwah. Dimana Istilah metode atau methodos (Yunani) diartikan sebagai rangkaian, sistematisasi dan rujukan tata cara yang sudah dibina berdasarkan rencana yang matang, pasti dan logis. 46

Strategi pada hakekatnya adalah perencanaan (planning) dan management untuk mencapai suatu tujuan. Tetapi untuk mencpai tujuan tersebut, strategi tidak hanya berfungsi sebagai peta jalan yang hanya menunjukkan arah saja, melainkan harus menunjukkan bagaimana tekhnik (cara) operasionalnya. Dengan demikian strategi dakwah merupakan perpaduan dari perencanaan (planning) dan management dakwah

\footnotetext{
${ }^{44}$ Ahmad Anas, Paradigma Dakwah Kontemporer, Aplikasi dan Praktisi Dakwah sebagai Solusi Problematikan Kekinian (Semarang: Pustaka Rizki Putra, 2006), Cet. Ke-1, h. 184.

45 Sutikno, http://sutiknotaliabo.blogspot.co.id/2013/05/strategi-dakwah.html, diakses pada tanggal 17 April 2016, pukul 12.00 WIB

${ }^{46}$ Onong Uchjana Efendi, Ilmu, Teori dan Filsafat Komunikasi (Bandung: PT. Citra Aditya Bakti, 2003), h. 56.
} 
untuk mencapai suatu tujuan. Di dalam mencapai tujuan tersebut strategi dakwah harus dapat menunjukkan bagaimana operasionalnya secara tekhnik (taktik) harus dilakukan, dalam arti kat bahwa pendekatan (approach) bias berbeda sewaktu-waktu bergantung pada situasi dan kondisi.

Untuk tercapainya strategi dakwah, maka segala sesuatunya harus dipertautkan dengan komponen-komponen yang merupakan jawaban terhadap pertanyaan dalam rumus Lasswell, yaitu:

a. Who? (Siapa da'i atau penyampai pesan dakwahnya?)

b. Says What? (Pesan apa yang disampaikan?)

c. In Which Channel? (Media apa yang digunakan?)

d. To Whom? (Siapa Mad'unya atau pendengarnya?)

e. With what Effect? (Efek apa yang diharapkan?) Pertanyaan "efek apa yang diharapkan" secara emplisit mengandung pertanyaan lain yang perlu dijawab dengan seksama.

f. When (Kapan dilaksanakannya?)

g. How (Bagaimana melaksanakannya?)

h. Why (Mengapa dilaksanakan demikian?) Tambahan pertanyaan tersebut dalam strategi dakwah sangat penting, karena pendekatan (approach) terhadap efek yang diharapkan dari suatu kegiatan dakwah bisa berjenis-jenis, yakni :

1) Menyebarkan Informasi

2) Melakukan Persuasi

3) Melaksanakan Instruksi.

2. Pentingnya Strategi Gerakan Dakwah 
Pentingnya strategi gerakan dakwah adalah untuk mencapai tujuan, sedangkan pentingnya suatu tujuan adalah untuk mendapatkan hasil yang diinginkan. Fokus perhatian dari ahli dakwah memang penting untuk ditujukan kepada strategi gerakan dakwah, karena berhasil tidaknya kegiatan dakwah secara efektif banyak ditentukan oleh strategi gerakan dakwah itu sendiri. Dengan demikian strategi gerakan dakwah, baik secara makro maupun secar mikro mempunyai funsi ganda, yaitu :

a. Menyebarluaskan pesan-pesan dakwah yang bersifat informatif, persuasif dan instruktif secara sistematik kepada sasaran untuk memperoleh hasil optimal.

b. Menjembatani "Cultur Gap" akibat kemudahan diperolehnya dan kemudahan dioperasionalkannya media yang begitu ampuh, yang jika dibiarkan akan merusak nilaii-nilai dan norma-norma agama maupun budaya. Bahasan ini sifatnya sederhana saja, meskipun demikian diharapkan dapat menggugah perhatian para ahli dakwah dan para calon pendakwah yang sedang atau akan bergerak dalam kegiatan dakwah secara makro, untuk memperdalaminya. Jika kita sudah tau dan memahami sifat-sifat mad'u, dan tahu pula efek apa yang kita kehendaki dari mereka, memilih cara mana yang kita ambil untuk berdakwah sangatlah penting, karena ini ada kitannya dengan media yang harus kita gunakan.

c. Cara bagaimana kita menyampaikan pesan dakwah tersebut, kita bias mengambil salah satu dari dua tatanan di bawah ini :

1) Dakwah secara tatap muka (face to face)

a) Dipergunakan apabila kita mengharapkan efek perubahan tingkah laku (behavior change) dari mad'u. 
b) Sewaktu menyampaikan memerlukan umpan balik langsung (immediate feedback).

c) Dapat saling melihat secara langsung dan bisa mengetahui apakah mad'u memperhatikan kita dan mengerti apa yang kita sampaikan. Sehingga umpan balik tetap menyenangkan kita.

d) Kelemahannya mad'u yang dapat diubah tingkah lakunya relative, sejauh bisa berdialog dengannya.

2) Dakwah melalui media

a) Pada umumnya banyak digunakan untuk dakwah informatif.

b) Tidak begitu ampuh untuk mengubah tingkah laku.

c) Kelemhannya tidak persuasif.

d) Kelebihannya dapat mencapai mad'u dalam jumlah yang besar.

3. Peranan Da'i Dalam Strategi Gerakan Dakwah

Dalam strategi gerakan dakwah peranan dakwah sangatlah penting. Strategi gerakan dakwah harus luwes sedemikian rupa sehingga da'i sebagai pelaksana dapat segera mengadakan perubahan apabila ada suatu faktor yang mempengaruhi. Suatu pengaruh yang menghambat proses dakwah bisa datang sewaktu-waktu, lebih-lebih jika proses dakwah berlangsung melalui media. Menurut konsep A. A. Prosedure, bahwa dalam melancarkan komunikasi lebih baik mempergunakan pendekatan, apa yang disebut A. A. Proceedure atau From Attention to Action Procedure yang di singkat AIDDA. Lengkapnya adalah sebagai berikut : A Attention (Perhatian), I Interest (Minat), D Desire (Hasrat), D Decision (keputusan), A Action (Kegiatan). Maknanya : 
a. Proses pentahapannya dimulai dengan membangkitkan perhatian (attention). Dalam hal ini pada diri seorang da'i harus menimbulkan daya tarik (source attactiveness).

b. Sikap da'i berusaha menciptakan kesamaan atau menyamakan diri dengan mad'u sehingga menimbulkan simpati mad'u pada da'i.

c. Dalam membangkitkan perhatian hindarkan kemunculan himbauan (appeal) yang negative sehingga menumbuhkan kegelisahan dan rasa takut.

d. Apabila perhatian mad'u telah terbangkitkan, hendaknya disusul dengan upaya menumbuhkan minat (interest) yang merupakan derajat lebih tinggi dari perhatian.

e. Minat adalah kelanjutan dari perhatian yang merupakan titik tolak bagi timbulnya hasrat (desire) untuk melakukan suatu kegiatan yang diharapkan mad'u.

f. Hasrat saja pada diri mad'u belum berarti apa-apa, sebab harus dilanjutkan dengan keputusan (decission), yakni keputusan untuk melakukan kegiatan (action) sebagaimana diharapkan da'i.

4. Tujuan Strategi Gerakan Dakwah

Dengan strategi gerakan dakwah seorang da'i harus berfikir secara konseptual dan bertindak secara sistematik. Sebab komunikasi tersebut bersifat paradigmatik. Paradigma adalah pola yang mencakup sejumlah komponen yang terkorelasikan secara fungsional untuk mencapai suatu tujuan. Suatu paradigma mengandung tujuan. Dan tujuan pada paradigma tesebut, yakni mengubah sikap, opini atau pandangan dan perilaku". (to change the attitude, opinion and behavior), sehingga timbul pada diri mad'u efek afektif, efek kognitif, dan efek konatif atau behavioral. Diantaranya : ${ }^{47}$

47 Husin Ismail, http://uchinfamiliar.blogspot.co.id/2009/04/strategi-dakwah-melaksanakaninstruksi.html, diakses pada tanggal 17 April 2016, pukul 11.31 WIB 


\section{a. Proses Dakwah}

Dalam menyusun strategi dakwah harus menghayati proses komunikasi yang akan dilancarkan. Proses dakwah harus berlangsung secara "berputar"(circular), tidak "melurus" (linear). Maksudnya, pesan yang sampai kepada mad'u efeknya dalam bentuk tanggapan mengarus menjadi umpan balik. Mengevaluasi efek dari umpan balik terseut negative atau positif.

b. Da'i

Mendalami pengetahuan Alqur'an dan Hadits, pengetahuan huukum Islam lainnya. Sejarah nabi, ibadah, muamalah, akhlak, dan pengetahuan Islam lainnya. Menggabungkan pengetahuan lama dan modern. Menguasai bahasa setempat. Mengetahui cara berdakwah, system pendidikan dan pengajaran, mengawasi dan mengarahkan. Berakhlak mulia. Para da'i harus bijaksana, dan berpenampilan yang baik. Para da'i haus pandai memilih judul, dan menjauhkan yang membawa kepada keraguan. Da'i adalah imam dan pemimpin. c. Pesan Dakwah

Sistematis dan objektif. Bahasanya ringan sesuai dengan situasi dan kondisi. Tidak harus panjang lebar. Pesan dakwah sesuai dengan Alqur'an dan Hadits. Meyakinkan tidak meragukan. Isinya menggambarkan tema pesan secara menyeluruh.

d. Media Dakwah

Radio, Mimbar, Televisi, Dan Publikasi lainnya, Film Teater, Majalah, Reklame, Surat Kabar

e. Mad'u 
Komponen yang paling banyak meminta perhatian. Sifatnya, heterogen dan kompleks. Selektif dan kritis memperhatikan suatu pesan dakwah, khususnya jika berkaitan dengan kepentingannya

5. Perkembangan Strategi Gerakan Dakwah

Kurun waktu perjuangan Rasulullah Saw. telah kita lewati sejak 14 abad yang lalu. Sebuah perjuangan dan pengorbanan dalam menjalankan misi yang diembankan keatas pundak beliau untuk berdakwah menyeru dan mengajak seluruh manusia agar mengesakan Allah SWT sebagai Tuhan yang sebenar untuk disembah dan mengajak agar manusia mengakui beliau adalah salah seorang utusan Allah. Secara singkat dakwah Rasulullah boleh dikatakan sangat berhasil. Melanjutkan misi dakwah Rasulullah tersebut juga mempetahankan dan melestarikan hasil jerih payah yang telah beliau tinggalkan, yaitu ajaran Islam.

Konteks strategi gerakan dakwah yang dulu dan sekarang tentu berbeda karena memang situasi dan tantangannya berbeda pula. Namun tujuan dan sasaran dakwah haruslah tetap sama yaitu tauhidillah. Dulu Rasulullah Saw. berdakwah dalam situasi dan kondisi dimana kebanyakan manusia benar-benar tidak mengenal Allah Swt. dan sama sekali tidak tahu tentang norma-norma akhlak yang terpuji. Yang ada hanya kekejaman, kekerasan tak berprikemanusiaan, seperti merampas hak-hak orang lain, mengubur hidup-hidup anak perempuan dan kebiasaan mabuk-mabukan.

Semua itu bukanlah hal yang asing bagi masyarakat dakwah Rasulullah saat itu. Caci maki dan penyiksaan bahkan pengucilan dilancarkan dengan gencarnya oleh kaum kafir Quaraisy tehadap pengikut Nabi Muhammad Saw. Mereka melakukan hal itu semua agar Gerakan Dakwah Islamiyah menjadi sempit sekaligus agar bisa menjadi propaganda kepada orang-orang bahwa siapa yang memilih beriman berarti ia memilih penderitaan. 
Perubahan zaman tentu diiringi dengan datangnya tantangan dan problematika yang lebih banyak, sulit menghadapinya, baik masa sekarang maupun di masa yang akan datang.

Muhammad Qutb dalam bukunya yang berjudul "Jahiliyah Abad XX” menyinggung gejala-gejala kemunduran dunia keabad-abad sebelumnya 'Return to back future'. Kemunduran yang beliau maksudkan adalah seolah-olah kemajuan peradaban yang pesat yang terjadi di saat ini tak ada bedanya dengan peradaban Yunani dan Romawi pada masa lampau. Dimana kemajuan ekonomi, politik dan ilmu pengetahuannya mampu mendominasi sebagian besar pelosok-pelosok dunia, termasuk Jazirah Arab.

Tapi mengapa masa tersebut disebut masa kebodohan (jahiliyah). Jawabannya adalah karena kemajuan yang mereka capai dalam segi material tidaklah begitu bernilai dibanding kemajuan dalam segi spiritual. Itu karena mereka mempertuhankan kemajuan tersebut sementara jiwa mereka kosong dari keimanan kepada Allah Swt. Dan malah justru kemajuan tersebut membuat mereka menjadi tidak percaya dengan adanya hari akhirat. Kejahiliyahan spiritual juga berbentuk penafian terhadap hukum Allah, sebagaimana yang difirmankan oleh Allah Swt:

"Apakah mereka mengehendaki hukum jahiliyah? Dan hukum siapakah yang lebih baik daripada hukum Allah bagi orang-orang yang yakin". (QS. Al-Ma'idah: 50). ${ }^{48}$

Dalam pembahasan strategi gerakan dakwah di abad modern, kita tak bisa melepaskan diri dari upaya memahami situasi yang ada, yaitu bahwa tantangan Dakwah Islamiyah saat ini adalah jahiliyah modern yang memiliki gambaran sebagai berikut: ${ }^{49}$

\footnotetext{
${ }^{48}$ Departemen Agama RI, Al-Qur'an dan Terjemah, (Jakarta : Maghafirah Pustaka, 2006), h. 120

49 Khairy Abusyairi, http://kmkmmedia.blogspot.co.id/2013/03/strategi-dakwah-islamiyah-dijaman.html, di akses pada tanggal 17 April 2016, pukul 10.02 WIB
} 
Tidak beriman kepada Allah SWT, atau tidak adanya keyakinan mutlak atas ketuhanan Allah dan keyakinan bahwa Dia-lah satu-satunya yang berhak atas ketentuan hukum.

a. Adanya pemerintahan thagut di muka bumi yang memalingkan manusia dari syari'at Allah Swt.

b. Kerusakan di bidang pemikiran seperti paham sekularisme, komunisme dan sebagainya.

c. Kerusakan di bidang moral.

d. Kerusakan di bidang politk, ekonomi sosial, seni budaya dan lain-lain.

Semua fenomena diatas sangat memerlukan solusi yang tepat dan benar. Memahami objek dakwah sangat menetukan metode penyampaian yang akan dipergunakan. Namun strategi dakwah dalam menghadapi tantangan seperti yang tersebut diatas secara umum antara lain:

a. Memahami betul manhaj dakwah Rasulullah Saw. mentauladani Rasulullah dari segi kepribadian, sifat dan sikap beliau dalam berdakwah.

b. Jadilah qudwah hasanah (contoh yang baik) bagi semua orang. Karena hal ini membuat dakwah kita lebih mudah diterima dan berkesan kuat di hati orang lain.

c. Mengantisipasi segala bentuk tantangan dakwah dengan konsekuensi harus mangamalkan ajaran agama Islam dalam kehidupan sehari-hari.

d. Berusaha memurnikan kembali pemahaman terhadap Islam yang diselewengkan serta menandingi arus gerakan westernisasi dan kristenisasi dengan memperbanyak media dakwah yang memungkinkan seperti mempergunakan televisi, radio, media cetak dan sebagainya. 
Dakwah butuh strategi, bukan sekedar asal-asalan dalam berdakwah. Strategi ini bisa dipraktikkan dalam ruang lingkup kecil di tengah-tengah keluarga, kerabat, hingga masyarakat secara umum. Menurut Syaikhul Islam Ibnu Taimiyah yang dihimpun oleh Muhammad Abduh Tuaskial, ada beberapa strategi gerakan dakwah, diantaranya : ${ }^{50}$

a. Dakwah yang pertama adalah dakwah tauhid dan pembinaan akidah.

b. Prioritaskan materi dakwah yang lebih penting: dakwah pada tauhid, baru dakwah pada amalan yang lebih penting, dan tidak mesti langsung pada perkara parsial (juz'iŷât).

c. Dakwah mesti dengan cara yang tepat dengan memperhatikan kondisi masyarakat.

d. Dakwah pada dalil dari Al-Qur'an dan As-Sunnah, jangan sampai dakwah tanpa dalil, tanpa mengikuti tuntunan.

e. Dakwah itu mengajak orang melakukan perintah dan menjauhi larangan (amar makruf nahi mungkar).

f. Berdakwah sesuai kemampuan.

g. Kemungkaran yang nampak wajib diingkari.

h. Mengingkari dalam hati lalu lisan didahulukan daripada mengingkari dengan tangan.

i. Mengingkari kemungkaran hanya boleh dengan hujjah (dalil) yang jelas.

j. Tidak boleh mengingkari kemungkaran dengan hal yang lebih mungkar.

k. Siapa yang menghadiri suatu acara kemungkaran dengan pilihan hatinya, maka ia dihukumi seperti melakukan kemungkaran tersebut.

1. Melarang sesuatu kemungkaran hendaklah mengarahkan juga pada hal yang manfaat lainnya, bukan sekedar melarang.

${ }^{50}$ Syaikhul Islam Ibnu Taimiyah, Qawa'id wa Dhawabith Fiqh Ad-Da'wah 'Inda, (Kairo : Dar Ibnul Jauzi, tt.t, 2010), Cet. Ke-2 
m. Hendaklah yang berdakwah menyelamatkan bahaya dirinya sebelum bahaya pada orang lain. 51

Perkawinan dalam Islam diatur sedemikian rupa, oleh karena itu perkawinan sering disebut sebagai perjanjian suci antara seorang laki-laki dan seorang perempuan untuk membentuk keluarga yang bahagia. Salah satu tujuan syariah Islam (Maqasid Al-Syari"ah) sekaligus tujuan perkawinan adalah hifz an-nasl terpeliharanya kesucian keturunan manusia sebagai pemegang amanah khalifah fi al-ard. Tujuan syariah ini dapat dicapai melalui jalan perkawinan yang sah meurut agama, diakui oleh undang-undang dan diterima sebagai bagian dari budaya masyarakat.52 Dalam pandangan Islam perkawinan itu bukanlah hanya urusan perdata semata, bukan pula sekedar urusan keluarga dan masalah budaya, tetapi masalah dan peristiwa agama, oleh karena perkawinan itu dilakukan untuk memenuhi sunnah Allah dan sunnah Nabi dan dilaksanakan sesuai dengan petunjuk Allah dan petunjuk Nabi. Disamping itu, perkawinan juga bukan untuk mendapatkan ketenangan hidup sesaat, tetapi untuk selama hidup. 53

Dengan adanya perkawinan maka timbulah hak dan kewajiban suami istri dalam rumah tangga, yang dimaksud dengan hak disini adalah apa-apa yang diterima oleh seseorang dari orang lain, sedangkan yang dimaksud dengan kewajiban adalah apa yang mesti dilakukan seseorang terhadap orang lain. Dalam hubungan suami istri dalam rumah tangga suami mempunyai hak dan begitu pula istri mempunyai hak. Dibalik itu suami mempunyai beberapa kewajiban dan begitu pula si istri mempunyai beberapa kewajiban.54 Sebagaimana firman Allah dalam alQur"an surat al-Baqarah ayat 228:

Artinya : "Wanita-wanita yang ditalak handaklah menahan diri (menunggu) tiga kali quru' 55. tidak boleh mereka Menyembunyikan apa yang diciptakan Allah dalam rahimnya, jika mereka beriman kepada Allah dan hari akhirat. dan suami-suaminya berhak merujukinya dalam masa menanti itu, jika mereka (para suami) menghendaki ishlah. dan Para wanita mempunyai hak yang seimbang dengan kewajibannya menurut cara yang

51 Muhammad Abduh Tuaskial, https://rumaysho.com/12184-strategi-dakwah-1.html, diakses pada tanggal 17 April 2016, pukul 11.43 WIB

52 Ahmad Rofiq, Hukum Isslam di Indoneia, cet. Ke-2, (Jakarta: PT Raja Grafindo Persada, 1997),

h. 220

53 Syariffuddun Amir, Hukum Perkawinan Islam di Indonesia, (Jakarta: Kencana, 2014), h. 48.

54 Ibid., h. 159

55 Quru' dapat diartikan suci atau haidh. 
ma'ruf. akan tetapi Para suami, mempunyai satu tingkatan kelebihan daripada isterinya56. dan Allah Maha Perkasa lagi Maha Bijaksana." 57

Ayat ini menjelaskan bahwa istri mempunyai hak dan istri juga mempunyai kewajiban. Kewajiban istri merupakan hak bagi suami. Hak istri semisal hak suami yang dikatakan dalam ayat ini mengandung arti hak dan kedudukan istri semisal atau setara atu seimbang dengan hak dan kedudukan suami. Meskipun demikian, suami mempunyai kedudukan setingkat lebih tinggi, yaitu sebagai kepala keluarga, sebagaimana diisyaratkan oleh ujung ayat tersebut diatas.

Mekanisme nafkah dalam Kompilasi Hukum Islam (KHI) terdapat dalam pasal 77 dan 78 .

\section{Pasal 77}

(1) Suami-istri memikul kewajiban yang luhur untuk menegakkan rumah tangga yang sakinah, mawaddah, dan rahmah yang menjadi sendi dasar dari susunan masyarakat.

(2) Suami-istri wajib saling cinta mencintai, hormat menghormati, setia dan memberi bantuan lahir batin yang satu kepada yang lain.

(3) Suami-istri memikul kewajiban untuk mengasuh dan memelihara anakanak mereka, baik mengenai pertumbuhan jasmani, rohani maupun kecerdasanya dan pendidikan agamanya.

(4) Suami-istri wajib memelihara kehormatanya.

(5) Jika suami atau istri melalaikan kewajibanya, masing-masing dapat mengajukan gugatan kepada Pengadilan Agama.

(1) Suami-istri mempunyai tempat kediaman yang tetap.

(2) Rumah kediaman yang dimaksud dalam Ayat (1), ditentukan oleh suamiistri bersama.

Pasal-pasal diatas menguraikan bahwa suami sebagai kepala rumah tangga adalah nahkoda dalam menjalankan rumah tangganya. Suami memiliki hak dan kewajiban, dan begitu pula istri. Masing-masing suami istri jika menjalankan kewajibanya dan memperhatikan tanggung jawabnya, akan terwujud ketentraman dan ketenangan hati sehingga sempurnalah kebahagiaan suami-istri tersebut.58

Menurut fitrah, laki-laki wajib menanggung semua urusan diluar rumah. Ini berlaku pada semua umat peradaban. Sedangkan wanita, menurut fitrahnya bertugas untuk mengandung anak, menyusuinnya, mengasuhnya dan mendidik mereka, selain mengurus perkara-perkara rumah tangga, wanita menguasai semua urusan internal rumah.59

Demikian pendapat As-Sayyid Muhammad Ridha. Nafaqah merupakan kewajiban suami terhadap istrinya dalam bentuk materi, karena kata nafaqah itu sendiri berkonotasi materi.60 Sedangkan yang termasuk dalam pengertian nafaqah menurut yang disepakati ulama" adalah sembilan bahan pokok pakaian dan

${ }_{56} \mathrm{Hal}$ ini disebabkan karena suami bertanggungjawab terhadap keselamatan dan

Kesejahteraan rumah tangga (Lihat surat An Nisaa' ayat 34)

57 Departemen Agama RI, Al-Qur"an dan Terjemahannya, h. 36.

58 As-Sayyid Sabiq, Fiqih as-sunnah, alih bahasa. Moh Thalib, cet. Ke-13 (Bandung: Al-Ma"arif, 1997), VII, h. 51

59 As-Sayyid Muhammad Rasyid Ridha, Risalah Hak dan Kewajiban Wanita, alih bahasa Isnando (Jakarta: Pustaka Qalami, 2004), h. 53.

60 Op.Cit, Syariffuddun Amir, Hukum Perkawinan Islam di Indonesia..., h.165. 
perumahan atau dalam bahasa sehari-hari disebut sandang, pangan, dan papan selain dari tiga hal tersebut menjadi perbincangan di kalangan ulma".61

Nafkah artinya mengelurkan belanja. Menurut istilah syara" artinya sesuatu yang dikeluarkan oleh seseorang untuk keperluan dirinya atau keluarganya yang berupa makanan, minuman, pakaian dan sebagainya.62 Yang menyebabkan wajib nafkah ialah : Sebab perkawinan yang sah, Sebab kerabat, Sebab milik.

Kewajiban memberikan nafaqah oleh suami kepada istrinya yang berlaku dalam fiqih didasarkan kepada prinsip pemisahan harta antara suami dan istri, prinsip ini mengikuti alur fikir bahwa suami itu adalah pencari rezeki, rezeki yang telah diperoleh itu menjadi haknya secara penuh dan untuk selanjutnya suami berkedudukan sebagai pemberi nafaqah. Sebaliknya istri bukan pencari rezeki dan untuk memenuhi keperluanya ia berkedudukan sebagai penerima nafaqah.63

Jumhur ulama termasuk ulama" Syi"ah imamiyah berpendapat bahwa nafaqah itu mulai diwajibkan semenjak dimulainya kehidupan rumah tangga, yaitu semenjak suami telah bergaul dengan istrinya dalam arti istri telah memberikan kemungkinan kepada suaminya untuk menggaulinya, yang dalam fiqih disebut dengan tamkin. Dengan semata terjadinya akan nikah belum ada kewajiban membayar nafaqah. Berdasarkan pendapat ini bila telah berlangsunya akad nikah istri belum melakukan tamkin karena keadaanya ia belum berhak menerima nafaqah. (al-Thusy, VI:11).64

Para ulama selain Hanafiyah berpendapat bahwa pernikahhan mewajibkan seorang suami memberikan nafkah, bahkan jika istri tersebut kafir, jika melalui pernikahan yang sah. Tetapi jika pernikahan itu fasid, maka suami berhak meminta nafkah yang telah diambil oleh istrinya.65

Menurut imam Asy-Safi"i, suami wajib memberikan nafkah harian, sebagai konsekuensi penyerahan istri kepada suami, kewajiban nafkan karena perkawinan ada tujuh macam, yaitu membeikan makan, memberikan pakaian, memberikan laukpauk, memberikan alat perawatan tubuh, memberikan rumah, memberikan perhiasan rumah, dan menyediakan pembantu jika memang istri membutuhkanya.66

Di Indonesia banyak bermunculan kelompok atau ormas Islam seperti LDII, HTI, Sidiqiyyah, FPI dan Jamah Tabligh. Namun penulis meneliti kelompok Jamaah Tabligh dikarenakan kelompok atau jamaah ini lebih aktif dibidang dakwah dengan metode yang dinamakan khuruj fii sabilillah (keluar di jalan Allah). Para jamaah terjun langsung kepada setiap elemen masyarakat dengan ketentuan kurun waktu secara bertahap 3 hari dalam setiap bulan, 40 hari dalam setiap tahun dan 4 bulan setiap tahun.

Ketika dalam masa berdakwah atau khuruj meninggalkan istri dan anakanaknya kewajiban sebagai kepela rumah tangga harus tetap terpenuhi salah satunya adalah kewajiban memberikan nafkah terhadap keluarganya.

Jadi kesejahteraan masyarakat sangat tergantung terhadap suami sebagai kepala keluarga yang mampu melaksanakan kewajiban nafkah terhadap istri dan

61 Ibid, Syariffuddun Amir, Hukum Perkawinan Islam di Indonesia..., h. 166.

62 Zainal Abidin S dan Ibnu Mas"ud, Fiqih Madzhab Syafi"I (Bandung: Pustaka Setia, 2007), h.

425.

63 Ibid., Syariffuddun Amir, Hukum Perkawinan Islam di Indonesia..., h. 165

64 Ibid, Syariffuddun Amir, Hukum Perkawinan Islam di Indonesia..., h. 168.

65 Wahbah az-Zuhaili, Al-Figh Al-Islam Wa"dillatuhu jilid X Terrjemahan Abdul Hayyi al-Qotani dkk, (Jakarta: Gema Insani \& Darul Fikir, 2011), h. 110.

66 Wahbah Zuhaili, Al- Figh asy-Syafi"l al-„Ami, Terjemahan Muhammad Afifi dan Abdul Aziz, jilid III, cet. I, (Jakarta: Al-Mahira, 2010), h. 42 
keluarganya, para ulama madzhab sepakat bahwa nafkah untuk istri itu wajib yang meliputi tiga hal pangan, sandang dan papan.67

\section{Jama'ah Tabligh \\ Pengertian}

Kata Jamaah tabligh berasal dari bahasa Arab sedangkan secara pengertian adalah gerakan trasnasional yang bergerak dari kalangan bawah, kemudian merangkul seluruh masyaakat muslim tanpa memandang tingkatan sosial dan ekonominya dalam mendekatkan diri kepada ajaran islam sebagaimana yang dibawa oleh Nabi Muhammad Saw.127

Jamaah Tabligh didirikan pada akhir dekade 1920-an oleh Maulana Muhamma Ilyas Kandhalawi di Mewat, sebuah provinsi di India. Tabligh resminya bukan merupakan kelompok atau ikatan, tapi gerakan muslim untuk menjadikan muslim yang menjalankan agamanya dan hanya satu-satunya gerakan islam yang tidak memandang asal-usul madzhab atau aliran pengikutnya.

Motif berdirinya Jamaah Tabligh adalah sebuah keinginan kuat untuk memperbaiki kondisi umat, terutama daerah Mewat yang hidup jauh dari ilmu dan lekat dengan kebodohan serta keterbelakangan. Keadaan umat islam di

123 Ibrahim Muhammad al-Ja"bari, Gerakan Kebangkitan Islam, alih bahasa Abu Ayyub alAnsary, (Solo : Duta Rohman, 1996), h. 67-70

124 Abu Mufdal al-Raghib al-Ashifany, al-Mufradat fi Gharib Al-Qur"an, (Damaskus : Dar Qalam, tt.), Juz 1, h. 226

125 A. Ilyaz Ismail, Paradigma Dakwah Sayyid Quthub Rekonstruksi Pemikiran Dakwah Harakah, (Jakarta : Penamadani, 2006), h. 12

126 Muhammad al-Ghazali, Fi Maukib al-Da"wah, (Kairo : Maktabah Nahdah al-Misr, 2005), h.163

h. 5

127 Ali Nadawi, Riwayat Hidup dan Usaha Dakwah Maulana M.Ilyas, (Yogyakarta: As-Shaff, 1999), 
sebagian besar dunia pada saat itu sudah rusak dan penuh dengan kebodohan, kefasikan dan kekufurran. Mereka benar-benar meniru tingkah laku jahiliyah yang pertama. 128

Di indonesia, Jamaah Tabligh berkembang sejak 1952 dibawa oleh rombongan dari India yang dipimpin oleh Miaji Isa. Tapi gerakan ini mulai marak pada awal 1970.129 Didalam Jamaah Tabligh, masing-masing bermadzhab menurut keyakinan masing-masing. Ada yang bermadzhab Hanafi, Maliki, Hambali ataupun Madzhab Syafii seperti kebanyakan kaum muslimin di Indonesia, Malaysia, Singapura, Bruney Darussalam, Philipina, dan Sekitarnya.

Tidak mungkin mereka itu tidak bermadzhab. Walaupun diakai sebagaimana masyarakat awam pada umumnya, bahwa kalangan awam Jamaah Tabligh tidak mengikuti ajaran madzhab mereka secara patuh. Hal itu karena ketidak sempatan mereka untuk memperdalam masalah madzhab, sehingga mereka mengikuti sekedar pengetahuan mereka. Namun demikian, secara umum mereka tetap mengikuti arahan dan bimbingan alim ulama masingmasing ditempat mereka.130

Walaupun Jamaah Tabligh tidak memiliki organisasi secara formal, namun kegiatan dan anggotanya terkoodinir dengan baik sekali. Bahkan mereka memilki detabase lengkap sekali. Dimulai dari penanggung jawab mereka untuk seluruh dunia yang dikenal dengan Ahli Syura di Nizamudin, New Delhi, India. Pimpinan mereka disebut Amir atau Zamidar atau Zumindar. Kemudian dibawahnya ada Syura Negara, misalnya: Indonesia, Malaysia, Amerika dan lain-lain. Menurut pengaukuan mereka ada lebih dari 250 negara yang memiliki markaz seperti masjid kebon jeruk Jakarta.131

Setiap 4 bulan mereka berkumpul musyawarah Negara masing-masing kemudian dibbwa ke musyawarah dunia di Nizamuddin. Musyawarah harian ada di mahalah masing-masing untuk memikirkan orang kampung mereka masing-masing sehingga biarpun ada yang pergi tasykil tetaplah ada orang di maqami yang menganggap dakwah di sana. Jamaah ini mengklaim mereka tidak menerima donasis dana dari manapun untuk menjalankan aktivitasnya. Biaya oprasional Tabligh dibiayai ssendiri oleh pengikutnya.132

Jama"ah Tabligh merupakan sekelompok atau segolongan kaum yang menyeru kepada yang ma"ruf dan mencegah dari yang mungkar, menyampaikan (tabligh) seruan Allah dengan landasan iman (laillaha ila llah). Agar iman tertanam dalam setiap diri dan tercipta lah rahmatan lil alamin yang dilandasi

128 Khusniati Rofiah, Dakwah Jamah Tabligh \& Eksistensinya Di Masyarakat, (Ponorogo: Press, 2010), h. 54-55.

129 Ibid., h. 56

130 Abdurrahman Ahmad As-Sirbuny, Kupas Tuntas Jama "ah Tabligh, (Cirebon: Pustaka Nabawi, 2012), h. 127

${ }_{131}$ Op.Cit, Khusniati Rofiah, Dakwah Jama"ah Tabligh \& Eksistensinya Di Mata Masyarakat..., h. 56 132 Ibid., Khusniati Rofiah, Dakwah Jama"ah Tabligh \& Eksistensinya Di Mata Masyarakat..., h. 56 
oleh Al-Qur"an dan hadits. Jama"ah Tabligh adalah jama"ah yang sangat intens melakukan dakwah.133

Maulana Muhammad Ilyaz rahmatullah alaih ketika melulai kegiatan dakwah tabligh ini mengatakan "Aku tidak memberikan nama apa pun terhadap usaha ini. Tetapi, seandainya aku memberinya nama, tentu aku menamakannya "gerakan iman"." Beliau menyadari bahwa memberikan suatu nama khusus pada kegiatan ini berarti membuat pengelompokan baru pada ummat. Ada umat yang aggota dan yang bukan anggota.Sedangkan dakwah dan tabligh adalah suatu amal ibadah seperti shalat, puasa, dzikir, dan sebagainya.Sebagaimana dalam ibadah-ibadah lain tidak ada pengelompokan dan keanggotaan (misalnya kelompok ahli shalat, ahli puasa dan lain-lain) demikian pula halnya dengan dakwah tablgih.

Selain hal itu, dakwah adalah tanggung jawab setiap individu ummat ini yang harus mereka tunaikan tanpa kecuali. Bila bentuk satu kelompok dakwah, tentu akan timbul bahwa dakwah adalah tugas anggota kelompok dakwah saja. Dengan berbagai pertimbangan itu Maulana Ilyaz tidak memberikan nama terhadap usaha dakwah tablgih.

Sedangkan "Jama"ah Tabligh" hanyalah sebutan untuk memudahkan saja.Sebutan tersebut bukan berarti ada anggota dan ada yang bukan anggota. Orang-orang mengikuti program keluar selama beberpa hari, setelah selesai akan kembali ketempat tinggalnya dan menjalankan aktifitas sebagaimana biasa, di tambah dengan usaha untuk berdakwah kepada orang-orang di sekitarnya.

"Jaulah" dalam bahasa Arab berarti keliling. "Jaulah"sendiri sebenarnya adalah satu program yang dilakukan setiap hari oleh jama"ah yang sedang keluar.Program serupa diadakan juga seminggu sekali di rumah-rumah sekitar masjid sendiri. Satu rombongan terdiri dari lima sanpai sepuluh orang mendatangi tiap-tiap rumah, menyampaikan pentingnya iman, amal shaleh, dan mengundang laki-laki penghuni rumah mengikuti program muzakarah dan kultum di masjid. Program ini biasanya dilakukan setelah Ashar hingga menjelang Maghrib.134

Dari penjelasan diatas Jama"ah Tabligh bukan lah nama dari gerakan ini, namun Jama"ah Tabligh hanyalah sebutan yang berasal dari masyarakat untuk memudahkan mengingat, keberadaan gerakan yang menyampaikan (tabligh) agama kepada ummat seluruh alam. Karena awal mula gerakan ini dibuat oleh Maulana Ilyaz rahmatullah alaih di Mewat, India saat itu tidak diberi nama. Jika gerakan ini diberi nama niscaya beliau akan menamai dengan gerakan Iman untuk membentuk sifat yakin kepada Allah Swt.

\section{Simpulan}

133 Ibid.,Khusniati Rofiah, Dakwah Jama"ah Tabligh \& Eksistensinya Di Mata Masyarakat..., h. 78 134 Mulwi Ahmad Harun Al-Rosyid, Meluruskan Kesalahpahaman Terhadap Jaulah (Jama"ah Tabligh), (Magetan : Pustaka Haromain, 2004), Cet. Ke-2, h.22 
Berdasarkan hasil penelusuran dan pembahasan tentang analisis hukum nafkah dalam keluarga Gerakan Dakwah Jama"ah Tabligh, dapat ditarik kesimpulan bahwa:

1. Jama'ah Tabligh merupakan sebuah gerakan dakwah yang empat ciri yang sangat menonjol, yaitu (1) murni dan autentik (dzâtiyyâh), yakni autentik sebagai panggilan Tuhan, (2) mendorong kemajuan (taqaddûmîyah), yakni kemajuan yang tetap menjunjung tinggi nilai-nilai moralitas, (3) universal (syamîlâhi) mencakup semua aspek kehidupan, memadukan tiga sistem hidup (manhaj al hayat) yang terdiri dari tiga D, yaitu Din (agama), Dunya (dunia), dan Daulah (pemerintahan negara) dan (4) menekankan prinsip-prinsip agama yang luhur dan menjauhkan diri dari perbedaan mazhab. Berdasarkan penelitian dan wawancara yang penulis teliti, gerakan dakwah Jama'ah Tabligh di kalangan wanita dalam pembinaan keluarga muslim di Kota Bandar Lampung telah berhasil dengan adanya peningkatan keimanan, peningkatan amal shalih, dan kesadaran diri pada kepahaman agama dalam setiap individu keluarga.

Dalam hukum positif Indonesia, permasalahan nafkah atau pemenuhan kebutuhan keluarga juga telah diatur dan dinyatakan menjadi kewajiban suami. Hal ini sesuai dengan Undang-undang No. 1 Tahun 1974, pasal 34 ayat (1) dan dipertegas oleh KHI Pasal 80 ayat (4). Keberadaan nafkah tentu mempunyai pengaruh dan fungsi yang sangat besar dalam membina keluarga yang bahagia, tenteram dan sejahtera. Tidak terpenuhi nafkah sama sekali atau nafkah yang tidak cukup dapat berakibat krisis perkawinan yang berujung pada perceraian.

Suami harus memprioritaskan hak istri dan anaknya baik materil (lahir) maupun immaterial sebelum menginggalkan keluarga untuk melaksanakan khuruj fii sabilillah (keluar di jalan Allah) 3 hari, 40 hari, 4 bulan seperti yang disebutkan oleh Yusuf Qardawi dalam fikih prioritas yaitu mengutamakan hakhak manusia atas hak-hak Allah. Dan berdasarakan Kompilasi Hukum Islam (KHI) tentang kewajiban suami terhadap isteri pasal 80 ayat 4a. Selama suami dapat memenuhi hak dan kewajibannya pada pasal tersebut saat melakukan kegiatan khuruj fii sabilillah maka tidak akan terdapat penyimpangan yang dilakukan oleh Jamaah tabligh. 


\section{Referensi}

A. Azhar Basyir, Hukum Perkawinan Islam. juga Fuad Kauma \& Nipan, Membimbing Istri

A. Ilyaz Ismail, Paradigma Dakwah Sayyid Quthub : Rekonstruksi Pemikiran Dakwah Harakah, (Jakarta : Permadani, 2006), Cet.Ke-1,

Abdu al-Jaziri, al-Figh alal mazahibil al-arba"ah, Juz 4, Cet I (Daar al-afaq al-arabiah, al-Qahirah, 2005)

Abdul Gani Abdullah, Pengantar Kompilasi Hukum Islam dalam Tata Hukum Indonesia, (Jakarta: Gema Insani Press, 1994)

Abdurrahman Ahmad As-Sirbuny, Kupas Tuntas Jama"ah Tabligh, (Cirebon: Pustaka Nabawi, 2012)

Abdurrahman al-Jaziri, kitab al-Fiqh „ala Madzhabi al-Arba"ah, (Beirut: Dar al-Kutub al-,„Imiyah, 1969), juz. IV

Abdurrahman, Kompilasi Hukum Islam di Indonesia, (Jakarta: CV Akademika Pressindo, 1995)

Abu Mufdal al-Raghib al-Ashifany, al-Mufradat fi Gharib Al-Qur"an, (Damaskus : Dar Qalam, tt.), Juz 1

Ahmad Rofiq, Hukum Isslam di Indoneia, cet. Ke-2, (Jakarta: PT Raja Grafindo Persada, 1997)

Ahmad Tirmidzi, dkk, Ringkasan Fikih Sunnah Sayyid Sabiq, (Jakarta: Pustaka AlKautsar. 2013)

Ahmad Warson Munawir, Kamus al Munawwir, (Yogyakarta: Pondok Psantren al Munawwir, 1984)

Ahmad Warson Munawwir, Kamus Al Munawwir Arab- Indonesia.cet ke 20,( Surabaya: Pustaka Progressif, 2002)

Ali Nadawi, Riwayat Hidup dan Usaha Dakwah Maulana M.Ilyas, (Yogyakarta: AsShaff, 1999)

Aliy As"ad, Terjemahan Fat-Hul Mu"in, Jilid 3, Menara Kudus, t.t,

As-Sayyid Muhammad Rasyid Ridha, Risalah Hak dan Kewajiban Wanita, alih bahasa Isnando (Jakarta: Pustaka Qalami, 2004)

As-Sayyid Sabiq, Fiqih as-sunnah, alih bahasa. Moh Thalib, cet. Ke-13 (Bandung: AlMa"arif, 1997), VII

Departemen Agama RI, Al-Qur"an dan Terjemahannya

Diknas, Kamus Besar Bahasa Indonesia, (Jakarta: Balai Pustaka, 2002), Edisi ketiga

Fuad Kauma dan Nipan, Membimbing Istri Mendampingi Suami (Yogyakarta: Mitra Pustaka, 2003)

Hasan Ibn Falah al-Qattany, al-Tariq ila al-Nahdah al-Islamiyyah, (Riyad : Dar alHamidi, 1993)

Ibnu Manzhur. Lisãn al- Arab. Jilid. 4 ( Bairut: Dãr-Elfikr. 1990)

Ibnu Rasyi Al Hafid, Bidayatul Mujtahid dan Nihayatul Muqtashid juz II, Jilid 1-6 bab Huququ Al Zaujiyah (Beirud: Dar Ibnu Asshahah, 2005)

Ibrahim Muhammad al-Ja"bari, Gerakan Kebangkitan Islam, alih bahasa Abu Ayyub al-Ansary, (Solo : Duta Rohman, 1996

Ilyas Ismail dan Prio Hotman, Filsafat Dakwah : Rekayasa Membangun Agama dan Peradaban Islam, (Jakarta : Prenada Media Group, 2011), Cet. Ke-1

Imam Syafi"i, Ringkasan Kitab Al-Umm, jilid 3-6, Terjemah Muhammad Yasir cet.ke3, (Jakarta:Pustaka Azzam,2007)

Khusniati Rofiah, Dakwah Jamah Tabligh E Eksistensinya Di Masyarakat, (Ponorogo: Press, 2010) 
Muhamad Uwaidah, Syah Kamil, Fiqih Wanita, (Jakarta: Pustaka Al Kaustar, 2008)

Muhammad Abu Zahrah, al-Ahwal al-Syakhshiyyah, (t.t, Dar al-Fikr al-,Arabi, 1957), cet. III

Muhammad al-Ghazali, Fi Maukib al-Da"wah, (Kairo : Maktabah Nahdah al-Misr, 2005)

Muhammad Jawad Mugniyah, Figh Lima Mazhab, Cet. 12 (Jakarta: Lentera, 2001)

Mulwi Ahmad Harun Al-Rosyid, Meluruskan Kesalahpahaman Terhadap Jaulah (Jama"ah Tabligh), (Magetan : Pustaka Haromain, 2004), Cet. Ke-2

Munir Fuady, Konsep Hukum Perdata, PT Raja Grafindo Persada, (Jakarta: 2014)

Proyek Pembinaan Prasarana dan Sarana Perguruan Tinggi Agama/IAIN Jakarta, Ilmu Fiqh Jilid II, (Jakarta: Direktorat Jenderal Pembinaan Kelembagaan Agama Islam Departemen Agama. 1984/1985)

Raghib al-Ashfahani, al-Mufradat fi Gharib al-Qur"an, (Beirut Libanon : Dar alMa"rifah, tt.) Lihat pula, Ibn Manzhur, Lisan al-Arab, (Beirut : Dar Shadir, 1990), Cet. Ke-1

Sayyid Sabiq, (Red) Moh. Tholib, Fikih Sunnah/Sayyid Sabiq, (Bandung: Alma"arif. 1997)

Sayyid Sabiq, Fiqih Sunnah Juz II, (Beirut: Darul Fikri, 2006), lihat Al Hamdani, Risalah Nikah

Simi Niazi, A New Paradigm in the Making, dalam Kalim Siddiqui (Ed.) Issues in the Islamic Movement 1980-1981 (1400-1401), (London-Toronto-Pretoria : The Open Press Limited, 1982)

Subaidi, Konsep Nafkah Menurut Hukum Perkawinan Islam, Vol. 1 No. 2 (Desember, 2014)

Sulaiman Rasjid, Fiqih Islam, (Jakarta : Attahiriyah, 1996)

Syaikh Abu Bakar Jabir al-Jaza"iri, "Minhajul Muslim”, terjemah Musthafa Aini dkk Cet. ke-1, (Jakarta: Darul Haq, 2006)

Syamsuddin Muhammad bin Muhamamd al-Khatin al-Syarbini, Mugni al-Muhtaj, (Bairut: Dar-al-Kutub al-Ilmiyah, tt), Juz V,

Syamsul Bahri, Konsep Nafkah dalam Hukum Islam, No. 66, Th. XVII (Agustus, 2015)

Syariffuddun Amir, Hukum Perkawinan Islam di Indonesia, (Jakarta: Kencana, 2014)

Tim Redaksi Kamus Besar Bahasa Indonesia, Kamus Besar Bahasa Indonesia, (Jakarta: PT Gramedia Pustaka Utama, 2008)

Wahbah al-Zuhaili, al-Figh al-Islam wa Adillatuhu, (Beirut: Dar al-Fikr, 1989), jilid II, cet. II Al-Figh Al-Islam Wa"dillatuhu jilid X Terrjemahan Abdul Hayyi al-Qotani dkk, (Jakarta: Gema Insani \& Darul Fikir, 2011) Al- Fiqh asy-Syafi"l al-,,Ami, Terjemahan Muhammad Afifi dan Abdul Aziz, jilid III, cet. I, (Jakarta: Al-Mahira, 2010)

Yusuf al-Qardawy, Sahwat al-islamiyah wa Humun al-Watan al-„Arab wa al-Islami, (Kairo : Makhtabah Wahbah, 1997) Fikih Prioritas Urutan Amal Terpenting Dari yang Penting, (Jakarta: Gema Insani Press, 1996)

Zainal Abidin S dan Ibnu Mas"ud, Fiqih Madzhab Syafi"I (Bandung: Pustaka Setia, 2007) 